\title{
Purification and Some Properties of Chitinase from the Stomach of Red Sea Bream Pagrus major*1
}

\author{
Michiko Kono, ${ }^{* 2}$ Takashi Matsui, ${ }^{* 8}$ and Chiaki Shimizu*2 \\ (Accepted June 2, 1986)
}

\begin{abstract}
Chitinase was purified from the stomach of red sea bream Pagrus major by fractionations with ammonium sulfate, Sephadex G-100 gel filtration, DEAE-cellulose, CM-cellulose and hydroxylapatite column chromatography. The purified enzyme showed a single band on disc and SDS polyacrylamide gel electrophoresis and the molecular weight was estimated to be 46,000 . The isoelectric point was 8.3. The optimum temperature and $\mathrm{pH}$ were $50^{\circ} \mathrm{C}$ and 5.5 , rerpectively. The activity was completely inhibited by $\mathrm{Hg}^{2+}$, strongly inhibited by $\mathrm{Fe}^{2+}$ and $\mathrm{Sn}^{2+}$, and slightly activated by $\mathrm{Cu}^{2+}$. The products of hydrolysis of chitin with the enzyme were $\mathrm{N}$-acetylglucosamine and $N, N^{\prime}$-diacetylchitobiose.
\end{abstract}

Chitinase (EC 3.2.1.14) is an enzyme that is widely distributed in nature and plays an important part in the degradation of chitin. Chitinase occurs in many fishes ${ }^{1-5)}$ where it is produced by the digestive glands for the digestion of chitinous foods.4) It is also present in the blood and lymphomyeloid tissues as part of the defense system against parasites. ${ }^{3)}$

Concerning a few fishes, there have been attempts to describe the properties of chitinase, however research has been fragmentary and there are no reports on its purification and properties in detail. Previously, we recognized that cultured red sea bream and Japanese eel utilized chitin in their diets and had high activity of chitinase in their stomachs. ${ }^{18}$ ) This paper describes the purification methodology and some properties of chitinase obtained from the stomach of red sea bream.

\section{Materials and Methods}

\section{Stomach of Red Sea Bream}

Red sea bream juveniles were obtained from Hamaoka, Shizuoka Prefecture, Japan, and reared with krill and commercial eel diet for two years prior to the experiments. The test fish were starved for one day prior to sampling for enzyme extraction to ensure that the stomach was devoid of contents. Twenty fishes with a mean body weight of $800 \mathrm{~g}$ were caught and their stomachs were immediately removed. The stomachs were separated from fat and other tissues, washed with distilled water and quickly frozen at $-20^{\circ} \mathrm{C}$ to prevent enzyme degradation.

\section{Assay of Chitinase Activity}

Chitinase activity was measured with colloidal chitin as substrate. The reaction mixture containing $0.5 \mathrm{~m} l$ of $5.0 \mathrm{mg} / \mathrm{m} l$ colloidal chitin, $1.0 \mathrm{ml}$ of $10 \mathrm{~mm}$ acetate buffer, $\mathrm{pH} 5.0$, and $2.0 \mathrm{ml}$ of enzyme solution was incubated at $30^{\circ} \mathrm{C}$ with agitation for one $h$. The activity was measured according to two methods; one of them was the method of Okutani and Kimata ${ }^{\text {o) }}$ which determined the amount of the remaining chitin in the reaction mixture turbidimetrically, and the other was to determine the amount of $\mathrm{N}$-acetylglucosamine (NAG) liberated by the method of Reissig et al. ${ }^{7)}$ One unit of chitinase activity was defined as the amount of enzyme which decomposed one $\mathrm{mg}$ of chitin or liberated one $\mathrm{mg}$ of $\mathrm{NAG}$ at $30^{\circ} \mathrm{C}$ per $\mathrm{h}$.

\section{Protein Determination}

Protein concentration was determined by the method of Lowry et al. ${ }^{8>}$ or from the absorbance at $280 \mathrm{~nm}$.

Disc Gel Electrophoresis and SDS Polyacrylamide Gel Electrophoresis

Disc gel electrophoresis was carried out ac-

*1 Presented at Annual Spring Meeting of the Japanese Society of Scientific Fisheries on April 2, 1984, Tokyo.

*2 Fisheries Research Laboratory, Faculty of Agriculture, University of Tokyo, Maisaka, Hamana,

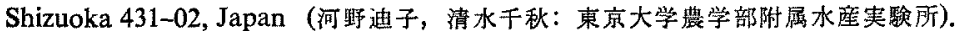

*3 Laboratory of Marine Biochemistry, Faculty of Agriculture, University of Tokyo, Bunkyo, Tokyo 113, Japan（松居 隆：東京大学婁学水崖化学研究室). 
cording to the method of Davis ${ }^{\beta)}$ at $\mathrm{pH} 8.3$ in $7.5 \%$ polyacrylamide gel. SDS polyacrylamide gel electrophoresis was performed according to the method of Hayashi and Ohba. ${ }^{10)}$ Cytochrome C monomer $(12,400)$, dimer $(24,800)$, trimer $(37,200)$, tetramer $(49,600)$, and hexamer $(74,400)$ were used as the marker proteins of the respective molecular weights. Enzyme and marker protein solutions were mixed with an equal volume of $0.02 \mathrm{M}$ phosphate buffer, $\mathrm{pH} 7.2$, containing $50 \%$ glycerine and $2 \%$ SDS, in the presence of $1 \% 2-$ mercaptoethanol. After incubation at $50^{\circ} \mathrm{C}$ for $2 \mathrm{~h}$, they were subjected to electrophoresis in $10 \%$ polyacrylamide gel. Both proteins were stained with $0.05 \%$ Coomassie brilliant blue R250.

\section{Isoelectro Focusing}

Isoelectro focusing of chitinase was performed with the micro isoelectro focusing apparatus (Fuji Riken Co., Ltd.). The purified enzyme $(0.3 \mathrm{mg})$ was applied on the column (capacity $3.5 \mathrm{~m} l$ ) with $0.1 \%$ agarose containing a carrier amphpolyte of pH 3.5-10.0. Electrophoresis was carried out at $4^{\circ} \mathrm{C}$ for $3 \mathrm{~h}$ at $300 \mathrm{~V}$. After electrofocusing, 0.15 $\mathrm{m} l$ of fractions were collected from the column for determination of $\mathrm{pH}$ and chitinase activity.

\section{- Amino Acid Analysis}

Chitinase was hydrolyzed with $6 \mathrm{~N} \mathrm{HCl}$ in vacuo at $110^{\circ} \mathrm{C}$ for 24 and $48 \mathrm{~h}$. The hydrolysates were analyzed with a Hitachi Model 835 amino acid analyzer. Tryptophan and half cystine were determined according to the methods of Simpson et al. ${ }^{11)}$ and Moore, ${ }^{12)}$ respectively.

\section{Thin Layer Chromatography}

The hydrolysates of colloidal chitin with the chitinase were detected by thin layer chromatography. The hydrolysis products were spotted on silica gel (Kieselgel $60 \mathrm{~F}_{254}, 0.25 \mathrm{~mm}$ thickness, Merck) plate and developed using ethyl acetate: pyridin: water (12:5:4) and n-butanol: acetic acid: water $(10: 3: 7)$. The spots were detected with the methods of Elson-Morgan, ${ }^{13)}$ Morgan-Elson, ${ }^{13)}$ and ninhydrin reagent. ${ }^{14)}$

\section{Chemicals}

Colloidal chitin was prepared according to the method of Tracey. ${ }^{15)}$ All the other chemicals were purchased from commercial chemical suppliers.

\section{Results and Discussion}

\section{Purification of Chitinase}

All operations in the purification of the enzyme were performed at $4-10^{\circ} \mathrm{C}$. Sixty-five $\mathrm{g}$ of stomach of red sea bream (20 fishes) was homogenized with 10 volumes of $0.15 \mathrm{M} \mathrm{NaCl}-10 \mathrm{mM}$ Tris $\cdot \mathrm{HCl}$, $\mathrm{pH} 7.4$, in a homogenizer, and the homogenate was centrifuged at $6,000 \mathrm{rpm}$ for $30 \mathrm{~min}$. After the supernatant was obtained, the precipitate was re-extracted with the same buffer and the supernatants were combined. The extract was brought to $65 \%$ saturation by adding solid ammonium sulfate. After standing overnight, the precipitate was collected by centrifugation at $6,000 \mathrm{rpm}$ for $30 \mathrm{~min}$ and dissolved in water. The solution was dialyzed against $0.15 \mathrm{M} \mathrm{NaCl}-10 \mathrm{~mm}$ Tris $\cdot \mathrm{HCl}$, $\mathrm{pH} 7.4$, and the dialysate $(110 \mathrm{~m} l)$ was applied to

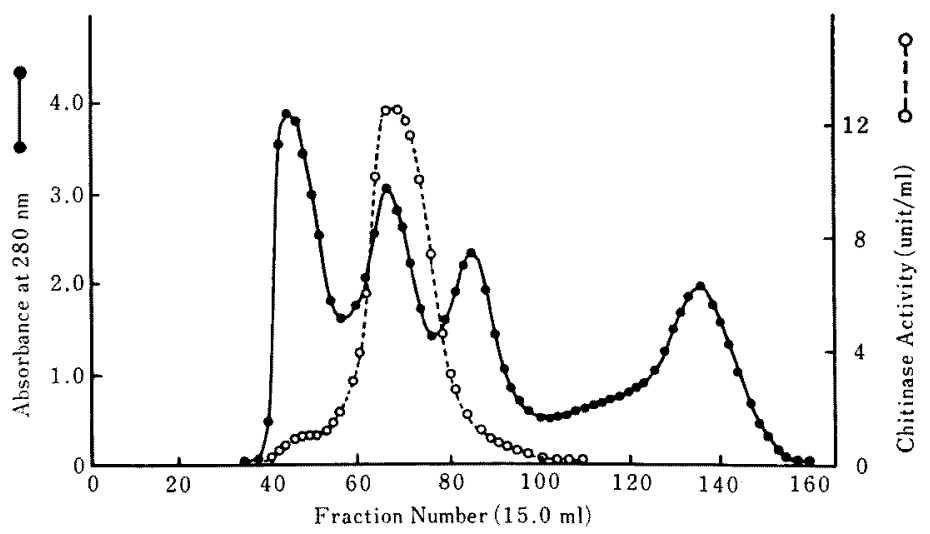

Fig. 1. Sephadex G-100 gel filtration of red sea bream chitinase.

Elution was carried out with $0.15 \mathrm{M} \mathrm{NaCl}-10 \mathrm{~mm}$ Tris $\cdot \mathrm{HCl}, \mathrm{pH} 7.4$, at a flow rate of $50 \mathrm{~m} l$ per $h$. 


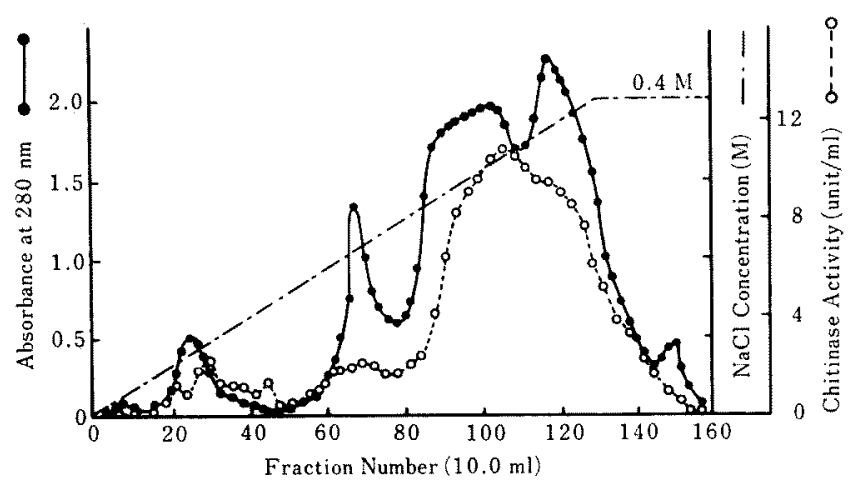

Fig. 2. DEAE-cellulose column chromatography of red sea bream chitinase.

Elution was carried out at a flow rate of $50 \mathrm{ml}$ per h with a linear $\mathrm{NaCl}$ gradient (0$0.4 \mathrm{M}$ ) equilibrated with $10 \mathrm{~mm}$ Tris $\cdot \mathrm{HCl}, \mathrm{pH} 8.0$.

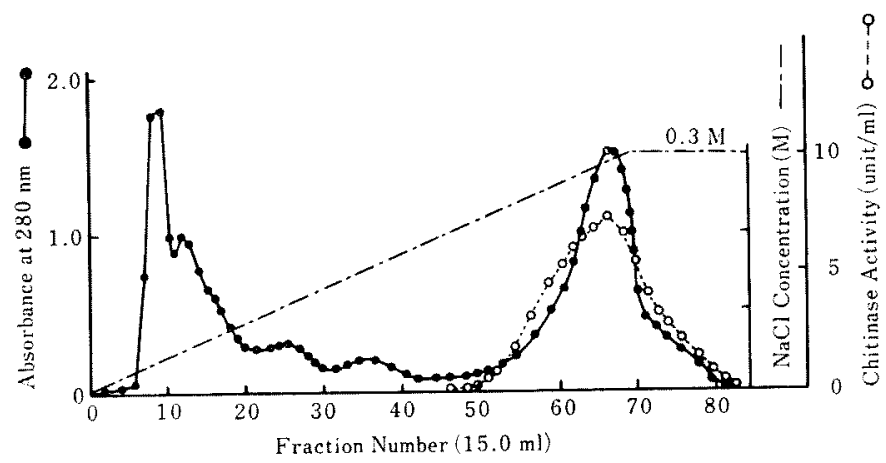

Fig. 3. CM-cellulose column chromatography of red sea bream chitinase.

Elution was carried out at a flow rate of $20 \mathrm{~m} l$ per h with a linear $\mathrm{NaCl}$ gradient $(0$ $0.3 \mathrm{M}$ ) equilibrated with $10 \mathrm{~mm}$ Tris $\cdot \mathrm{HCl}, \mathrm{pH} 7.4$.

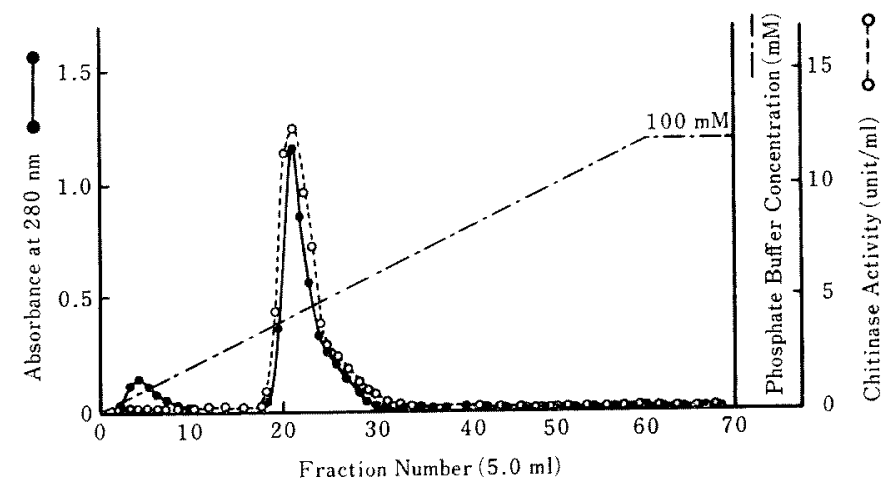

Fig. 4. Hydroxylapatite column chromatography of red sea bream chitinase.

Elution was carried out with a linear gradient of phosphate buffer, $\mathrm{pH} 6.9,(1-100 \mathrm{~mm})$ at a flow rate of $20 \mathrm{~m} l$ per $h$.

a Sephdex G-100 column $(5.2 \times 85.0 \mathrm{~cm})$ and eluted with the same buffer (Fig. 1). The active enzyme fraction were combined, concentrated with ammonium sulfate precipitation as described above, and subsequently dialyzed against $10 \mathrm{~mm}$ Tris $\cdot \mathrm{HCl}$, pH 8.0 (buffer A). The dialysate ( 85 $\mathrm{m} l$ ) was applied to a DEAE-cellulose column $(4.0 \times 23.0 \mathrm{~cm})$ previously equilibrated with buffer 
Table 1. Purification of chitinase from the stomach of red sea bream

\begin{tabular}{lccccc}
\hline \hline & $\begin{array}{c}\text { Volume } \\
(\mathrm{m} l)\end{array}$ & $\begin{array}{c}\text { Total } \\
\text { protein } \\
(\mathrm{mg})\end{array}$ & $\begin{array}{c}\text { Total } \\
\text { activity } \\
(\mathrm{U})\end{array}$ & $\begin{array}{c}\text { Specific } \\
\text { activity } \\
(\mathrm{U} / \mathrm{mg})\end{array}$ & $\begin{array}{c}\text { Yield } \\
(\%)\end{array}$ \\
\hline Extract & 1,400 & 5,600 & $5,700^{* 1}(610)^{* 2}$ & 1.0 & 100 \\
Ammonium sulfate ppt. & 220 & 2,120 & $4,510(480)$ & 2.1 & 79 \\
Sephadex G-100 & 800 & 1,550 & $3,570(440)$ & 2.3 & 63 \\
DEAE-cellulose & 630 & 750 & $3,130(350)$ & 4.2 & 55 \\
CM-cellulose & 200 & 122 & $1,510(140)$ & 12.4 & 27 \\
Hydroxylapatite & 200 & 53 & $890(120)$ & 16.8 & 16 \\
\hline
\end{tabular}

*1 One unit (1U) of chitinase activity was defined as an enzyme quantity which decomposed $1 \mathrm{mg}$ of chitin per $\mathbf{b}$.

*2 One unit (1U) of chitinase activity was defined as an enzyme quantity which liberated $1 \mathrm{mg}$ of $\mathrm{N}$-acetylglucosamine per h.

A. Enzyme was eluted with a linear gradient of $\mathrm{NaCl}$ from 0 to $0.4 \mathrm{M}$ in buffer A. As shown in Fig. 2, the chitinase fraction was obtained as a broad peak. The active enzyme fractions were combined, concentrated, and dialyzed against 10 $\mathrm{mm}$ Tris $\cdot \mathrm{HCl}$, pH 7.4 (buffer $\mathrm{B}$ ). The dialysate $(50 \mathrm{ml})$ was applied to a CM-cellulose column $(2.0 \times 32.0 \mathrm{~cm})$ equilibrated with buffer $B$. The column was eluted with a linear gradient of $\mathrm{NaCl}$ from 0 to $0.3 \mathrm{M}$ in buffer $\mathrm{B}$ (Fig. 3). The chitinase fractions were combined and concentrated with ultra filtration and then dialyzed against $1 \mathrm{~mm}$ phosphate buffer, pH 6.9 (buffer $\mathrm{C}$ ). The dialyzed solution $(50 \mathrm{ml})$ was applied to hydroxylapatite column $(1.5 \times 6.0 \mathrm{~cm})$ previously equilibrated with buffer $\mathrm{C}$, and eluted with a linear gradient of phosphate buffer from 1 to $100 \mathrm{~mm}$. The elution profile of the enzyme is shown in Fig. 4.

The yield and purity of chitinase at each purification step were summarized in Table 1. At the end of this study, the enzyme was purified 17 fold with a recovery of $16 \%$. The homogenity of this enzyme was determined with disc electrophoresis. As shown in Fig. 5, the chitinase migrated as a single band of protein.

\section{Molecular Weight}

The purified enzyme also migrated as single band on SDS polyacrylamide gel electrophoresis, and the molecular weight was estimated as 46,000 (Fig. 5, 6). This molecular weight was found to be similar to the value of chitinase in the pancreas of rabbit fish Chimaera monstrosa reported as 43,000.4) However, the molecular weight of the bacterial chitinase in Streptomyces erythraeus which was reported as 30,000 was significantly different from this value.

\section{Isoelectric Point}

As shown in Fig. 7, the isoelectric point of chitinase was estimated as 8.3. It was reported
(A)
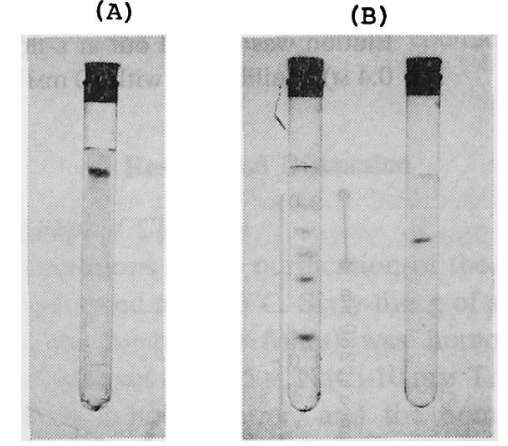

Fig. 5. Disc gel and SDS polyacrylamide gel electrophoretic patterns of red sea bream chitinase.

(A) disc gel electrophoresis. (B) SDS polyacrylamide gel electrophoresis. left; molecular marker proteins, right; red sea bream chitinase.

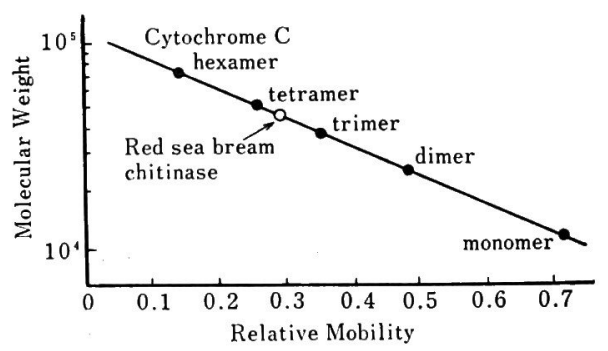

Fig. 6. Determination of molecular weight of chitinase by SDS polyacrylamide gel electrophoresis.

The molecular marker proteins were: Cytochrome C monomer, 12,400; dimer, 24,800; trimer, 37,200; tetramer, 49,600; hexamer, 74,400.

that the isoelectric points of chitinase in Chimaera monstrosa was 4.9, and that in Streptomyces orientalis which had two chitinases were 8.65 and 8.80. ${ }^{1 \theta)}$ As such the value determined in red sea bream is closer to the value reported in the latter. 


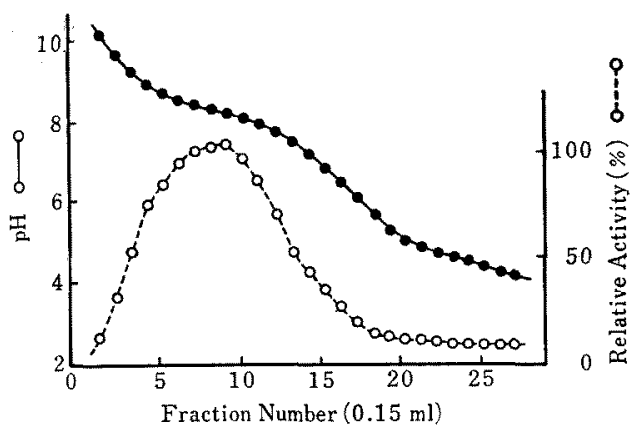

Fig. 7. Isoelectric focusing of red sea bream chitinase.

The purified enzyme $(0.3 \mathrm{mg})$ was electrofocused with a Fuji Riken TO column $(5.0 \times 160$ $\mathrm{mm}$ ). Electrophoresis was carried out at $4^{\circ} \mathrm{C}$ for $3 \mathrm{~h}$ at $300 \mathrm{~V}$.

Table 2. Amino acid composition of chitinase

\begin{tabular}{|c|c|c|}
\hline \multirow[b]{2}{*}{ Amino acid } & \multicolumn{2}{|c|}{ Residues per molecule (integer) } \\
\hline & Red sea bream & $\begin{array}{l}\text { Streptomyces } \\
\text { erythraeus* }\end{array}$ \\
\hline Aspartic acid & $41.5(42)$ & $37.5(38)$ \\
\hline Threonine & $26.2(26)$ & $22.9(23)$ \\
\hline Serine & $26.0(26)$ & $25.2(25)$ \\
\hline Glutamic acid & $35.4(35)$ & $21.7(22)$ \\
\hline Proline & $26.7(27)$ & $13.4(13)$ \\
\hline Glycine & $53.1(53)$ & $34.0(34)$ \\
\hline Alanine & $36.4(36)$ & $32.5(33)$ \\
\hline Valine & $19.9(20)$ & $18.2(18)$ \\
\hline Half-cystine & $11.7(12)$ & $4.1(4)$ \\
\hline Methionine & $5.3(5)$ & $4.7(5)$ \\
\hline Isoleucine & $11.2(11)$ & $12.5(13)$ \\
\hline Leucine & $29.0(29)$ & $15.0(15)$ \\
\hline Tyrosine & $22.9(23)$ & $7.3(7)$ \\
\hline Phenylalanine & $22.6(23)$ & $9.7(10)$ \\
\hline Tryptophan & $7.8(8)$ & $4.8(5)$ \\
\hline Lysine & $24.9(25)$ & $12.9(13)$ \\
\hline Histidine & $7.1(7)$ & $2.2(2)$ \\
\hline Arginine & $12.2(12)$ & $8.9(9)$ \\
\hline Molecular weight & 46,000 & 30,000 \\
\hline
\end{tabular}

\section{Amino Acid Composition}

The amino acid composition of red sea bream chitinase was shown in Table 2. For comparative purposes, the amino acid composition of chitinase derived from the bacteria Streptomyces erythraeus was shown in Table 2. Although the molecular weights were different from each other, the amino acid profiles were similar.
Table 3. Effects of metal ions and some reagents on chitinase activity

\begin{tabular}{lcc}
\hline \hline Reagents & $\begin{array}{c}\text { Concentration } \\
(\mathrm{mM})\end{array}$ & $\begin{array}{c}\text { Relative activity } \\
(\%)\end{array}$ \\
\hline None & - & 100 \\
$\mathrm{Ca}^{2+}$ & 2 & 104 \\
$\mathrm{Mg}^{2+}$ & $\prime \prime$ & 94 \\
$\mathrm{Mn}^{2+}$ & $\prime \prime$ & 88 \\
$\mathrm{Co}^{2+}$ & $\prime \prime$ & 106 \\
$\mathrm{Sr}^{2+}$ & $\prime \prime$ & 85 \\
$\mathrm{Fe}^{2+}$ & $\prime \prime$ & 55 \\
$\mathrm{Sn}^{2+}$ & $\prime \prime$ & 20 \\
$\mathrm{Cu}^{2+}$ & $\prime \prime$ & 127 \\
$\mathrm{Cd}^{2+}$ & $" \prime$ & 122 \\
$\mathrm{Hg}^{2+}$ & $\prime$ & 0 \\
EDTA & 20 & 96 \\
Iodoacetamide & 2 & 86
\end{tabular}

Effect of Temperature and $\mathrm{pH}$

As shown in Fig. 8 and 9, the optimum temperature and $\mathrm{pH}$ of the chitinase were $50^{\circ} \mathrm{C}$ and 5.5 , respectively.

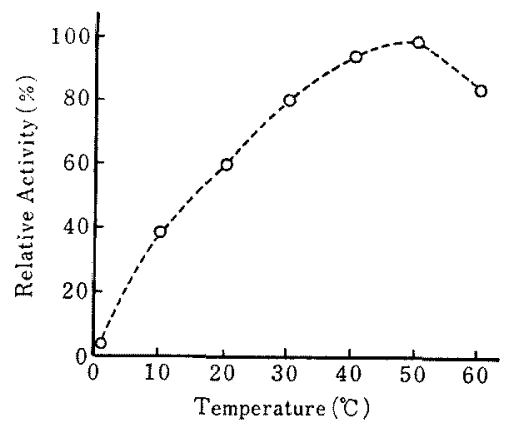

Fig. 8. Effect of temperature on chitinase activity.

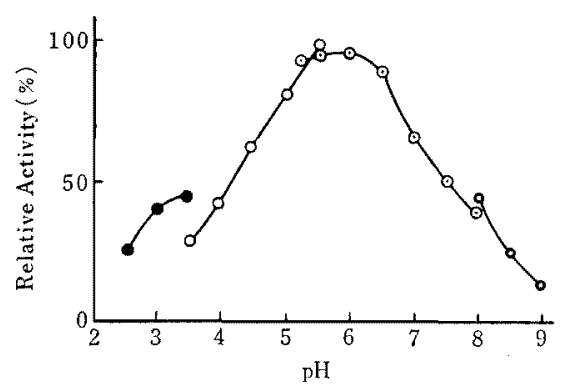

Fig. 9. Effect of $\mathrm{pH}$ on chitinase activity.

The buffer used were: $10 \mathrm{~mm}$ sodium acetate $\mathrm{HCl}$ buffer (-); sodium acetate acetic acid buffer $(\bigcirc-O)$; phosphate buffer $(\odot-\odot)$; Tris . $\mathrm{HCl}$ buffer $(\mathrm{O}-\mathrm{O})$. 


\section{Effect of Metal Ions and Some Reagents}

The effects of metal ions and some reagents on the activity of chitinase were shown in Table 3 . The enzyme activity was completely inhibited by $\mathrm{Hg}^{2+}$, and strongly inhibited by $\mathrm{Fe}^{2+}$ and $\mathrm{Sn}^{2+}$. On the other hand, the enzyme was slightly activated by $\mathrm{Cu}^{2+}$ and the addition of $20 \mathrm{mM}$ EDTA had little effect on enzyme activity.

\section{Hydrolysis Products of Chitin by Chitinase}

The reaction mixture consisting of $6.0 \mathrm{ml}$ of $0.5 \%$ colloidal chitin, $1.0 \mathrm{ml}$ of $10 \mathrm{~mm}$ acetate buffer, $\mathrm{pH} 5.0$, and $3.0 \mathrm{ml}$ of the chitinase solution with one drop of toluene was incubated at $25^{\circ} \mathrm{C}$ for $48 \mathrm{~h}$. The hydrolysates were surveyed with silica gel thin layer chromatography. As shown in Fig. 10, $N$-acetylglucosamine and $N, N^{\prime}$-diacetylchitobiose were detected.

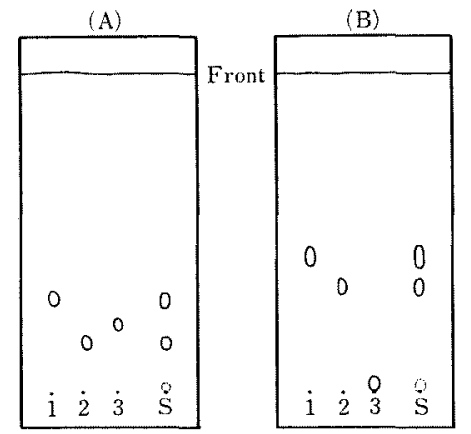

Fig. 10. Hydrolysis products of chitin with red sea bream chitinase.

Silica gel thin layer chromatography was carried out with two solvent system: $\mathrm{A} ; n$ butanol: acetic acid: water $(10: 3: 7), \mathrm{B}$; ethyl acetate: pyridine: water $(12: 5: 4) .1 ; N$-acetylglucosamine, $2 ; N, N^{\prime}$-diacetylchitobiose, 3; glucosamine, $\mathrm{S}$; hydrolysis products.

As described above, the properties of red sea bream chitinase were different from the other chitinase in fish or bacteria. In a previous study, we observed that the chitinase activity among red sea bream, Japanese eel, and yellowtail were in proportion to the growth rate when fed a diet supplemented with chitin. ${ }^{18)}$ After the methodology for purification of chitinase from the stomachs of eel and yellowtail was established, the relationship between chitin digestion and chitinase properties among these three fishes are now under investigation.

\section{Acknowledgement}

We wish to thank to Lecturer C.S. Hock, University Pertaniane Malaysia, for his reading the manuscript.

\section{References}

1) C. Jeuniaux: Nature, 192, 135-136 (1961).

2) K. Okutani: Bull. Misaki Mar. Inst., Kyoto Univ., 10, 1-47 (1966).

3) R. Fänge, G. Lundblad, and J. Lind: Mar. Biol., 36, 277-282 (1976).

4) R. Fänge, G. Lundblad, J. Lind, and K. Slettengren: Mar. Biol., 53, 317-321 (1979).

5) G. J. H. Lindsay, M. J. Walton, J. W. Adron, T. C. Fletcher, C. Y. Cho, and C. B. Cowey: Aquaculture, 37, 315-334 (1984).

6) K. Okutani and M. Kimata: Nippon Suisan Gakkaishi, 31, 232-237 (1965).

7) J. L. Reissig, J. L. Strominger, and L. F. Leloir: J. Biol. Chem., 217, 959-966 (1955).

8) O. H. Lowry, N. J. Rosebrough, A. L. Farr, and R. J. Randall: J. Biol. Chem., 193, 265-275 (1951).

9) B. J. Davis: Ann. N.Y. Acad. Sci., 121, 404-427 (1964).

10) K. Hayashi and Y. Ohba: Tanpakushitsu Kakusan Koso, 17, 304-311 (1972).

11) R. J. Simpson, M. R. Neuberger, and T. Y. Liu: J. Biol. Chem., 251, 1936-1940 (1976).

12) S. Moore: J. Biol. Chem., 238, 235-237 (1963).

13) S. M. Partrige: Biochem. J., 42, 238-250 (1948).

14) D. Aminoff and W. T. J. Morgan: Nature, 162, 579-580 (1948).

15) M. V. Tracey: Biochem. J., 61, 579-586 (1955).

16) Y. Tomonaga and Y. Tsujisaka: Agr. Biol. Chem., 40, 2325-2333 (1976).

17) S. Hara, Y. Yamamura, Y. Fujii, and T. Ikenaka: in "Chitin and Chitosan" (ed. by S. Hirano and S. Tokura), The Japanese Society of Chitin and Chitosan, Tottori University, Department of Agricultural Biochemistry, Tottori 680, Japan, 1982, pp. 125-130.

18) M. Kono, T. Matsui, and C. Shimizu: Nippon Suisan Gakkaishi, 53, 125-129 (1987). 